\title{
TOWARDS THE REALISATION OF JUSTICE IN THE NIGER DELTA: A SOCIO-LEGAL PERSPECTIVE
}

\author{
By Babatunde Fagbayibo*
}

'You do not interest me; no man can say these words to another without committing a cruelty and offending against justice.'

- Simone Weil ${ }^{1}$

\section{Introduction}

Apart from the brutal Nigerian civil war (1967 - 1970), nothing else has captured the conscience of the people of the world, vis-à-vis the Nigerian Federation, more than the plight of the people of Niger Delta. It remains the open sore (to borrow Wole Soyinka's phrase) of the Nigerian Federation. ${ }^{2}$ The devastating impact of oil exploration in the area has wreaked havoc of immeasurable proportions on the health, socio-economic and environmental conditions of the people. From the short-lived armed struggle of the late Isaac Adaka Boro in the 1960's, to the civil resistance method of the late Kenule Saro Wiwa in the early 1990's, and the present guerrilla tactics of the Movement for the Emancipation of the Niger Delta (MEND), the issue of the Niger Delta continues to beg for more constructive attention.

This paper aims to ascertain the (in)justice in the Niger Delta through an examination of the concept of justice, and subsequently to recommend strategies for redressing the inherent anomalies.

\section{$2 \quad$ A brief history of the Niger Delta}

Oil was first discovered in commercial quantities in Oloibiri, in the present day Bayelsa State, in 1956. The Niger Delta (also geopolitically referred to as the south-south region) covers an area of

* $\quad$ LLD candidate, Faculty of Law, University of Pretoria. This paper is an abridged version of a research paper submitted in 2006 towards the partial fulfilment of an LLM at the University of Pretoria. I sincerely appreciate the candid comments of Professor Karin van Marle on the draft of this paper.

1 Cited in $\mathrm{K}$ van Marle 'Lives of action, thinking, and revolt - a feminist call for politics and becoming in post apartheid South Africa' (2004) South African Public Law 626.

2 W Soyinka The open sore of a continent: A personal narrative of the Nigerian crisis (1996). 
about 70000 square kilometres; it covers roughly two-thirds of the entire coast of Nigeria. ${ }^{3}$ The Niger Delta is spread across nine out of the 36 states of Nigeria: Abia, Akwa Ibom, Bayelsa, Cross River, Delta, Edo, Imo, Ondo and Rivers States. ${ }^{4}$ The estimated population is about 20 million, with over 40 different ethnic groups speaking 250 different dialects across 3000 communities. Farming and fishing are the predominant occupations of the people. ${ }^{5}$

While oil accounts for 90 per cent of Nigeria's total export earnings and over 80 per cent of the government's revenue, ${ }^{6}$ the area remains the least developed in the country. ${ }^{7}$ According to a 1995 World Bank report, per capita income in the region is below the national average of the $\$ 280 .^{8}$ Health indicators are low; there is high fatality from water-borne diseases, malnutrition and poor sanitation. Less than 20 per cent of the area is accessible by good roads. ${ }^{9}$ Human and infrastructural development in the area is abysmally low. Agriculture and fishing, the main sources of livelihood of the people from time immemorial, have been destroyed by the devastating pollution caused by gas flaring and oil spillage. These neglects have aggravated the situation in the area.

These problems are largely as a result of a lack of responsible and accountable leadership at both the federal and local levels. The oil companies and businesses in the region have carried out oil exploration and extraction for over 50 years without proper environmental impact assessment. ${ }^{10}$ In spite of the successive agencies that have been created over the years - the Niger Delta Basin Development Board (NDBDB) in 1965; the Oil Minerals Producing Areas Development Commission (OMPADEC) in 1992; and the current Niger Delta Development Commission (NDDC) in 2000 - the plight of the people and the area they inhabit remains unchanged.

\section{The theory of justice}

Throughout history, no other philosophical concept has been as controversial and widely debated as justice. Justice seems elusive in a world bedevilled with ceaseless strife, a huge divide between the

'The Niger Delta: A brief history’ http://www.nddconline.org (accessed 20 June 2006).

As above.

5 E Alagoa A History of the Niger Delta (2005) 13-14.

6 N Budina \& $S$ van Wijnbergen 'Managing oil revenue volatility in Nigeria: The role of fiscal policy' http://siteresources.worldbank.org/INTDEBTDEPT/Resources/ 468980-1207588563500/4864698-1207588597197/AFRI427460Ch10.pdf (accessed 20 May 2008).

Soyinka (n 2 above).

http://www.ihrhl-ng.org/niger\%20delta.html (accessed 1 May 2008).

Soyinka (n 2 above).

As above. 
poor and the rich, unbridled unilateralism, famine, crippled economies, subjugation of the minorities, and institutional racial and gender discrimination. With all of these in mind, one is left with the inevitable questions: What is justice? Where is justice? How is justice measured? In order to gain a purposeful insight into this question, it is pertinent to take a philosophical incursion into the origin of this concept.

The idea of justice is said to have existed as early as the history of mankind. ${ }^{11}$ In the biblical Garden of Eden, the first administration of justice was exerted: The injunction not to touch the apple and the eventual conviction and sentencing as a result of the flouting of this order.

From here, we can escalate to the Greek period of 1000 BC by examining Aeschylus's trilogy, The Oresteia. ${ }^{12}$ The heroine in this ancient mythology, Electra, is the seeker of justice. She sought revenge against those who had killed her mother. The irony of the situation lies in the fact that it was Orestes - her brother - who had committed the heinous crime on the excuse of avenging their father's death. However, Electra did not want vengeance on her brother but on her enemies (read: hypocrisy). While the majority of judges found Orestes guilty, the Goddess Athena - using her casting vote acquitted Orestes. In order to console the aggrieved, Athena set up a human court to make sure that justice would henceforth be served.

Aristotle referred to justice as 'that kind of state of character that makes people disposed to do what is just and makes them act justly and wish for what is just'. ${ }^{13}$ He defines justice as 'giving everyone his due'. This is distributive justice. How does distributive justice giving everyone his or her due - fit into the Niger Delta question? By using all known parameters, can one safely say that the impoverished people of the Niger Delta have been given their due in terms of education, health, good roads and most importantly a realistic revenue allocation formula? As will be shown in the following, justice remains elusive in the Niger Delta.

According to the positivist school of thought, justice depends on man-made law - 'where there is no commonwealth, there nothing is just'. ${ }^{14}$ Hobbes believed that all laws:

have their authority and force from the will of the commonwealth; that is to say, from the will of the representatives ... the law ... is a

11 K Eso Anatomy of Justice (1990) 7-8.

12 C Douzinas \& A Gearey Critical jurisprudence: The political philosophy of justice (2005) 113-116.

13 Soyinka (n 2 above) 10.

14 Soyinka (n 2 above) 16-17. 
command, and a command consisteth in declaration or manifestation of the will of the commandeth. ${ }^{15}$

This statement implies that subjects are meant to obey any law regardless of its unreasonableness - as long as it comes from the sovereign. Could it thus be argued that the constitutional provision regulating the revenue allocation, and legislation regulating crude oil exploration in the Niger Delta, are valid in spite of the adverse effect it has on the people? These points will be considered later.

At this juncture, it is instructive to consider two modern day theorists, Roscoe Pound and John Rawls. Roscoe Pound ${ }^{16}$ considered law as a means of attainment of justice through social engineering. Rawls' idea of social justice is divided into two principles. According to him, the first principle implies that 'each person is to have an equal right to most extensive social system of equal basic liberties compatible with a similar system of liberty for all'. ${ }^{17}$

The second principle is that social and economic inequalities are to be arranged so that they are both: ${ }^{18}$

- to the greatest benefit of the least advantaged, consistent with the just saving principle; and

- attached to offices and positions open to all under conditions of fair equality of opportunity.

Can it be argued that the pursuit of socio-economic justice in the Niger Delta should be tailored along these lines?

\section{$4 \quad$ An analysis of the cases}

\subsection{Shell Petroleum Development Corporation v Adamkue ${ }^{19}$}

In this case, the appellant, Shell Development Company of Nigeria, had oil concessions all over the Ogoni area. In the course of their crude oil productions, they established flow stations from which crude oil is conducted through pipelines. On 31 July 1994, there was an explosion at one of the flow stations, which led to a massive spillage of crude oil. A large area of the land, creeks, rivers and forest were affected. The respondents, who are natives of the areas affected by the spillage, claimed to have suffered losses.

The Court of Appeal had to deal with inter alia the following issues, these being of the greatest significance to this article:

As above.

Soyinka (n 2 above) 22.

J Rawls A theory of justice (1971) 302.

As above.

G Fawehinmi \& A Olanrewaju (eds) Nigerian weekly law reports (2003) 451-670. 
- whether the respondents were entitled to any damages caused in respect of loss of earnings from fisheries, damage to water, creeks, etc because section 3(1) of the Minerals $\mathrm{Act}^{20}$ vested all natural resources in the state; and

- whether the oil spillage was as a result of the negligence of the appellant.

In dealing with the first issue, the judge held that while section 3(1) of the Minerals Act vests the control of minerals and oils under and upon any lands in Nigeria in the state, ${ }^{21}$ fishing within tidal waterways was free to all inhabitants of the country and citizens were entitled to establish temporary occupation on the banks of such waterways. ${ }^{22}$ When there is a violation of these rights, inhabitants, like any other owner, are entitled to compensation.

On the second issue, the judge held that the oil spillage would not have occurred if proper care was taken. ${ }^{23}$ The Court rejected the appellant's view that the accident was caused by vandals in the area, because this view was in conflict with the evidence of the police officer charged with the responsibility of guarding the pipeline. ${ }^{24}$

\subsection{Jonah Gbemre v Shell Petroleum Development Corporation; Nigerian National Petroleum Corporation and the Attorney General of the Federation ${ }^{25}$ (Gbemre case)}

This case is similar to the aforementioned. The plaintiff, Mr Gbemre of the Iwherekan community in Delta State Nigeria, sought a declaration compelling the defendants (first and second) to stop the continuation of gas flaring in his community without a valid Environmental Impact Assessment (EIA). He claimed that burning gas by flaring in his community has led to the pollution of the environment, exposure to diseases such as cancer, respiratory illnesses and chronic bronchitis, pollution of food and water, etc. ${ }^{26} \mathrm{He}$ also claimed that continued gas flaring in his community was a violation of the community's rights to life and to a clean, healthy, pollution-free environment, and the dignity of human persons guaranteed by the Constitution of Nigeria and the African Charter on Human and Peoples' Rights (Ratification and Enforcement) Act. ${ }^{27}$

Act 55 of 1945.

As above.

Fawehinmi \& Olanrewaju (eds) (n 19 above) 596.

Fawehinmi \& Olanrewaju (eds) (n 19 above) 594.

As above.

http://www.climatelaw.org/media/gas.flaring.suit.nov2005/ni.pleadings.doc (accessed 20 March 2006).

26 'Oil development in Nigeria: A critical investigation of Chevron Corporation's performances in the Niger River Delta' www.n-h-i.org/publicatios/pubs_pdf / Nigeria_corp Account.pdf (accessed 20 May 2006). 
The Court held that the continuation of gas flaring in the applicant's community is a violation of the constitutionally guaranteed rights to life (including a healthy environment) and dignity. In addition, it held that the failure of the first and second respondents to carry out EIA in the community is a violation of the section 2(2) of the Environmental Impact Assessment Act. ${ }^{28}$ The Court further held that the provisions of sections 3(2)(a) and (b) of the Associated Gas Re-Injection Act of 1979 and section 1 of the Associated Gas Re-Injection (Continued Flaring of Gas) Regulation, ${ }^{29}$ under which continued flaring of gas in Nigeria may be allowed, is inconsistent with the applicant's right to life and dignity.

The Court made an order of perpetual injunction restraining the defendants from further flaring gas in the applicant's community, and finally ordered the Attorney-General of the Federation to set in motion immediately, after due consultation with the Federal Executive Council, for the enactment of a bill by the National Assembly for the amendment of the relevant sections of the Associated Gas Regulation Act.

\subsection{Ethics and justice: any correlation?}

The striking similarities between these cases lie in the way the courts have dealt with certain legislation concerning oil exploration in the Niger Delta. The courts have boldly considered the effects of uncontrolled gas flaring in the area, ruling in the Gbemre case that both the government and oil companies must stop the further flaring of gas. It is important to discuss the two pieces of legislation that were considered in these cases.

Firstly, section 3(1) of the Minerals Act provides that:

the entire property in and control of all minerals, in, under or upon any lands in Nigeria, and of all rivers, streams and watercourse throughout Nigeria, is and shall be vested in the State, save in so far as such rights may in any case have been limited by any express grant made before the commencement of this Act.

Secondly, sections 3(2)(a) and (b) of the Associated Gas Re-Injection Act and section 1 of the Associated Gas Re-Injection (Continued Flaring of Gas) Regulations, allows for continued flaring of gas in Nigeria in spite of its devastating impact.

If one was to consider these provisions in the context of Austinian command positivism, Jeremy Bentham's 'pain and pleasure syndrome' and Hobbes' 'command of the sovereign', then one will find no fault with the contents of the aforementioned provisions. 
According to the positivist, justice is identified fully with law. ${ }^{30}$ Justice excludes the notion of ethics or morals. Situating this within the context of these judgments, the judges are expected not to find any fault with the content of the abovementioned provisions because they are the law. The consequences of these pieces of legislation, however, have little or nothing to do with the law. They fall within the scope of morals, which must be separated from the law. As aptly stated by Aristotle, 'evidently all lawful acts are in a sense just acts, for the acts drawn by the legislative act are lawful, and each of these, we say is just. ${ }^{31}$

To this extent, can it be argued that these provisions are just, since they are the laws of the land? But realistically speaking, will this help the precarious situation in the Niger Delta?

This is where ethics comes in. In analysing his phenomenology of judgment, Kennedy ${ }^{32}$ expressed that there is a conflict between the law and a judge's existential decision; that is, how he wants it to come out. ${ }^{33}$ A judge's existential decision is determined by his or her ethics, morals and understanding of his or her environment. In explaining his idea of indeterminate judgment, Aristotle ${ }^{34}$ defined practical wisdom or phronesis as the method of deliberation followed by the prudent, in order to arrive at judgments that will help achieve the standards of excellence of the various practices as a part of the wider project of establishing the good life.

Can it then be argued that the decisions in the aforementioned cases are in line with phronesis or ethics?

One would agree. In the Adamkue case, ${ }^{35}$ the judge held, in spite of the provisions of section 3(1) of the Minerals Act which vested the ownership of all minerals in Nigeria in the state, that the common right of fishing in tidal water is recognised and not affected by this provision. Recognising that fishing is the main occupation of the people in the area and also considering that the gross negligence of the oil companies has resulted in an oil spillage that has wreaked havoc of immeasurable proportions on the people and their environment, the judge could not help but give a wide interpretation to this otherwise restrictive provision so that justice could be served.

What role has phronesis or ethics played in the Gbemre case? It is clear that sections 3(2)(a) and (b) of the Associated Gas Re-Injection Act, which allows for continued flaring of gas without any Environmental Impact Assessment (EIA), is more business-friendly

Douzinas \& Gearey (n 12 above) 132.

Eso (n 11 above) 16.

Douzinas \& Gearey (n 12 above) 235-237.

Douzinas \& Gearey (n 12 above) 132.

Douzinas \& Gearey (n 12 above) 167.

Fawehinmi \& Olanrewaju (eds) (n 19 above) 595-596. 
than people-friendly considering its devastating impact. The Court held that this section is a clear violation of the community's rights to life and dignity. It further held that the continued gas flaring must be stopped and the government should amend the conflicting provisions. In situating this within the context of 'indeterminate judgment', one can easily deduce the role ethics has played in influencing the judge's decision. In deciding this case, the judge has been influenced by his sense of morals and conscience, largely shaped by his observance of the devastating effects of gas flaring in the Niger Delta, negligence on the parts of the government and oil companies, and a genuine drive to deliver a judgment that will contribute in a positive way to addressing the Niger Delta imbroglio.

While the judiciary has made strident efforts at making sure that legal justice and equity is applied to the Niger Delta question, one must not neglect certain impediments to the fulfilment of legal justice in the area. It has been observed that oil companies usually respond to litigation with continuous appeals, ensuring that litigants do not benefit from their legal victory. ${ }^{36}$ Another hindrance is the cost of bringing a case against the government and the oil companies, considering the fact that most of the litigants are impoverished and uneducated. ${ }^{37}$ In this regard, it is important that civil society play a more active role in ensuring that indigent litigants are assisted.

\section{$5 \quad$ The way forward}

It must be remembered that there is nothing more difficult to plan, more doubtful of success, or more dangerous to manage than the creation of a new order, for the initiator has the enmity of all who profit by the preservation of the old institution and merely lukewarm defenders in those who would gain by the new one. This was the infamous sentiment of Nicolo Machiavelli. ${ }^{38}$

The Niger Delta challenge remains the albatross hanging around the neck of the Nigerian Federation. No one can argue the fact that there is injustice in the Niger Delta. The reek of injustice pervades the society and can only be ignored at the peril of the Nigerian people. The legacy of 50 years of oil exploration in the Niger Delta includes disastrous ecological degradation, environmental pollution, and zero development. Over 50 per cent of the 70000 square kilometres of the territory has neither navigable roads nor hospitals. ${ }^{39}$

'Oil development in Nigeria: A critical investigation of Chevron Corporation's performances in the Niger River Delta' www.n-h-i.org/publicatios/pubs_pdf / Nigeria_corp Account.pdf (accessed 20 May 2006).

37 As above.

38 http://www.quotedb.com/authors/nicolo-machiavelli (accessed 1 August 2008).

39 'Editorial' The Guardian June 13 June 20062. 
How then do we translate these activist judgments into something concrete and substantial? To answer this germane question, it is instructive to employ the ideas of the aforementioned philosophers in mapping out the way forward.

\subsection{The greatest benefit}

John Rawls' idea of socio-economic justice implies that the greatest benefit should be given to the least advantaged, consistent with the just-saving principle. ${ }^{40}$ It is undeniable that the Niger Delta is the least advantaged if this theory is placed within the Nigerian context. The pertinent question is 'what constitutes the greatest benefits?'.

It has been suggested that what the Niger Delta needs is a "Marshal Plan' similar to the one given to Germany after the Second World War. Igiebor $^{41}$ suggested that there should be a ten year programme of socio-economic infrastructural development aimed at providing basic necessities such as potable water, modern education facilities, hospitals, power supply, and free education to tertiary level for indigenes, funded with a minimum of $\$ 1.5$ billion to $\$ 2$ billion. He also proposed the creation of a special saving-cum-investment fund specifically for the Niger Delta area for a time in future when the oil would run out.

On 18 April 2006, the Nigerian government adopted the report of the Consolidated Council of Socio-Economic Development of Constitutional State of the Niger Delta. ${ }^{42}$ The report suggested that the developmental programme in the Niger Delta be divided into:

- short term (now - two years);

- medium term (two - five years); and

- long term (five years and above).

The report further suggested that developmental programmes must include the federal government's intervention in the employment of indigenes, transport and road infrastructures, education, health, telecommunication, environment-friendly initiatives, agricultural development, and power and water resources. ${ }^{43}$

The greatest benefit requires a vibrant and genuine strategic approach by the government and the oil companies in order to create a sustainable development in the area. The Niger Delta people must also be involved in this process. Any process short of economically improving the lot of the Niger Delta people is reductive and will only exacerbate the already explosive situation in the area. The Niger Delta people not only deserve the greatest benefit because they have

Rawls (n 17 above) 302.

N Igiebor 'Cry the unbeloved Delta' (2006) Tell Magazine.

The Guardian 19 April 20065.

As above. 
been disadvantaged for a very long time, but because their area is the proverbial goose that lays the golden eggs.

\subsection{The mills of justice}

Roscoe Pound ${ }^{44}$ considered law as a means of attainment of justice through social engineering. The three mills of justice are:

- making of laws, that is legislation by legislators;

- interpretation of laws by the court; and

- application of laws, that is, achievement of purpose.

Interpretation of laws by the courts has earlier been discussed. What is considered now is the making of laws and the application of laws so that the purpose is achieved.

One of the greatest obstacles to the eradication of injustice in the Niger Delta is the 'derivation formula' in section 162(2) of the Nigerian Constitution: 45

$[P]$ rovided that the principle of derivation shall be constantly reflected in any approved formula as being not less than thirteen percent of the revenue accruing to the federation account directly from any natural resources.

In essence, this means that only a paltry 13 per cent of the pecuniary benefits derived from the sales of crude oil accrue to the nine states of the Niger Delta. Under the 1960 Independence Constitution, the Niger Delta area was recognised for special development initiative and attention. It recognised that a 50 per cent royalty deriving from oil and gas was to be paid to the oil producing area. ${ }^{46}$ This arrangement was in place until the advent of military rule in 1966. The 'royalty clause' has since been replaced with the 'derivation clause'.

There exists a need to overhaul the Nigerian Constitution so that every ethnic nationality has a sense of belonging. Being a diverse nation, what Nigeria needs is a proper federal constitution that reflects these realities, assuages the fears of the minorities and most importantly, entrenches the ethos of social justice and fairness. There should not be any place for laws that are intent on depriving people of their humanity or unnecessarily withholding their dues. It is imperative that national development is reshaped so that policies of the federal government give the utmost priority to oil producing areas.

Eso (n 11 above) 22.

Constitution of the Federal Republic of Nigeria 1999 (the Nigerian Constitution). Independent Constitution of Nigeria, $1960 \mathrm{sec}$ 134; Constitution of Nigeria 1963 sec 140. 
What is required is the immediate amendment of section 162(2) of the Nigerian Constitution so that it may reflect justice. The only way to achieve this is by stipulating a minimum royalty of 50 per cent deriving from oil and gas for oil producing states. ${ }^{47}$ This will go a long way in giving the people a sense of belonging and autonomy over their resources. Other measures like strict environmental laws, accountability of oil companies (for example, legislation making it compulsory for oil companies to plough back a stipulated percentage of their profits into both human and material development of the area), involvement of the indigenes in developmental activities and detailed developmental programmes, prioritised and given adequate attention.

\section{Conclusion}

The restoration of justice in the Niger Delta is not negotiable; it is in fact the only way out of this quagmire. The Nigerian government needs to demonstrate concerted and genuine political will by putting in place frameworks aimed at eradicating the continued marginalisation of the area. The Niger Delta people deserve a better deal from the Nigerian federation. The Niger Delta question is indeed the open sore of the Nigerian federation and only justice can heal this wound. The triumph of justice in the Niger Delta is thus imperative.

C Ikpatt 'Understanding the difference between percentage derivation and resource ownership' http://www.ngex.com/news/public/article.php?ArticlelD $=21$ (accessed 15 July 2008). Some Niger Delta activists have demanded a constitutional provision that guarantees full $(100 \%)$ royalties and rent while the Nigerian government only claims taxes and profit margin. 